\title{
Correction to: CD73 expression in normal and pathological human hepatobiliopancreatic tissues
}

\author{
Amedeo Sciarra ${ }^{1}(\mathbb{0})$ Inês Monteiro ${ }^{1} \cdot$ Christine Ménétrier-Caux $^{2} \cdot$ Christophe Caux $^{2} \cdot$ Benoit Gilbert $^{1}$. \\ Nermin Halkic ${ }^{3}$-Stefano La Rosa ${ }^{1} \cdot$ Pedro Romero $^{4} \cdot$ Christine Sempoux $^{1} \cdot$ Laurence de Leval $^{1}$
}

Published online: 5 February 2019

(c) Springer-Verlag GmbH Germany, part of Springer Nature 2019

\section{Correction to: Cancer Immunology, Immunotherapy https://doi.org/10.1007/s00262-018-2290-1}

The following information must be added to the published article:

Authors Amedeo Sciarra and Inês Monteiro contributed equally to this work and they share first co-authorship.

This information was unfortunately lost in the publication process of the manuscript.

Publisher's Note Springer Nature remains neutral with regard to jurisdictional claims in published maps and institutional affiliations.

Amedeo Sciarra and Inês Monteiro contributed equally to this work and they share first co-authorship.

The original article can be found online at https://doi.org/10.1007/ s00262-018-2290-1.

Christine Sempoux

christine.sempoux@chuv.ch

$\triangle$ Laurence de Leval

laurence.deleval@chuv.ch

1 Service of Clinical Pathology, Institute of Pathology,

Lausanne University Hospital, rue du Bugnon 25,

1011 Lausanne, Switzerland

2 Innovation in Immuno-monitoring and Immunotherapy Platform (PI3), Léon Bérard Cancer Center, Lyon, France

3 Department of Visceral Surgery, Lausanne University Hospital, Lausanne, Switzerland

4 Department of Oncology, Faculty of Biology and Medicine, University of Lausanne, Lausanne, Switzerland 